\title{
Effects of Scutellaria scordifolia Fisch. ex Schrank Extracts on Biofilm Formation and the Activities of Klebsiella pneumoniae
}

\author{
Keun-Dol Yook ${ }^{1}$, Nayoung $\mathrm{Ha}^{2}$ \\ ${ }^{1}$ Department of Clinical Laboratory Science, Daejeon Health Institute of Technology, Daejeon, Korea \\ ${ }^{2}$ Institute for Immunity, Transplantation and Infection, Stanford University School of Medicine, California, USA
}

\section{Klebsiella pneumoniae균의 바이오 필름 형성과 활성에 대한 병두황진 추출물의 효과}

\author{
육근돌 ${ }^{1}$, 하나영 ${ }^{2}$ \\ ${ }^{1}$ 대전보건대학교 임상병리과, ${ }^{2}$ 스탠포드의과대학교 면역, 이식, 감염 연구소
}

\begin{abstract}
The emergence of biofilms have generated urgent alarm in clinical and medicine manufacturing fields engaged in the search for novel antimicrobials from ethno-medicinal plants. The National Institutes of Health $(\mathrm{NIH})$ has estimated that $70 \%$ of all microbial infections in the world are associated with biofilms. In addition, the emergence of strains resistant to conventional antibiotics has become a serious threat to global public health. Therefore, finding alternative medicines is a major issue in the field of integrative medicine. In this study, four different herb extracts were screened for biofilm formation and the activities of Klebsiella pneumoniae. Of them, Scutellaria scordifolia Fisch. ex Schrank extracts had inhibitory effects on bacterial growth and biofilm formation. The Scutellaia scordifolia Fisch. ex Schrank extracts did not cause any cytotoxicity to L929 cells. The growth of K. pneumoniae was inhibited compared to other comparators in the experimental group containing Scutellaia scordifolia Fisch. ex Schrank. In a group of experiments with plant extracts, a maximum of 60 times the level of living bacteria was confirmed compared to the controls without the addition of the Scutellaia scordifolia Fisch. ex Schrank extracts. In a group of experiments with a significantly lower level of fluorescence extraction, differential interference contrast imaging showed that the number of $K$. pneumonae was reduced. These results suggest that extracts of this plant be applied as antimicrobial agents against $K$. pneumoniae, particularly in biofilm forms.
\end{abstract}

Key words: Alternative medicine, Biofilm, Plant extracts

This is an Open Access article distributed under the terms of the Creative Commons Attribution Non-Commercial License (http://creativecommons.org/licenses/by-nc/4.0) which permits unrestricted non-commercial use, distribution, and reproduction in any medium, provided the original work is properly cited.

Copyright $\odot 2018$ The Korean Society for Clinical Laboratory Science. All rights reserved.
Corresponding author: Keun-Dol Yook Department of Clinical Laboratory Science, Daejeon Health Institute of Technology, 21 Chungjeong-ro, Dong-gu, Daejeon 34504 Korea

Tel: 82-42-670-9169

Fax: 82-42-670-9582

E-mail:kdyook@hit.ac.kr

Received: September 17, 2018

Revised 1 ${ }^{\text {st: }}$ October 7, 2018

Revised $2^{\text {nd }}$ : October 9, 2018

Revised $3^{\text {rd }}$ : November 9, 2018

Accepted: November 9, 2018
서 론

수천 년 동안 Scutellaria 종의 화합물은 항 종양, 항균, 항 바 이러스제, 항염증제, 항산화 제 또는 간 보호 인자로 안전하게
사용되고 있다[1]. 심지어 Park 등[2]은 속이 같은 한국의 Scutellaria baicalensis Georgi 가 hepatocellular carcinoma cells (HCC)에 대한 강력한 화학 치료제가 될 수 있음을 시사하 기도 하였다. 천연추출물은 주로 식물성 성분 이 대부분으로 이 
들은 기존의 화학제나 합성제와 같은 치료제 보다는 독성이 없 거나 또는 있어도 매우 미미한 정도에 불과하기 때문에 각종치 료제로서의 신약개발에 있어서 관심의 대상이 되었다[3]. 각종 식물이나약초에서 추출된 천연물 중에는 탄닌(tannin)을 비롯 한 카로틴(carotene), 이소프렌(isoprene), 테르펜(terpene)등 다양한 물질들이 포함되어 있으며, 이들 은 각종 암에 유효한 항 암효과를 비롯하여 염증이나 세균에 대해 강력한 억제효과를 나타내는 항염이나 항균과 같은 다양한 생리활성을 가지고 있 다고 보고되고 있다[4]. 여러 종류의 천연 물질에 대한 항균효과 논문들이 많이 보고 되고 있지만 주로 대장균 또는 식중독 및 일 반병원세균에 대한 논문들이 대부분이다. 그리고 내성 세균에 대한 천연 물질의 항균 효과는 대부분 methicillin-resistant Staphylococcus aureus(MRSA)에 대한 연구만 보고되어 있는 실정이다 $[5,6]$. 따라서 현재 임상에서 문제를 야기하고 있는 다 양한 내성균에 대한 항균 효과에 대한 연구가 필요하고[7] 내성 세균의 증가는 공중 보건학적으로 커다란 문제를 야기하고 있 으며, 이러한 문제를 해결하기 위해 항균물질 대체 약제의 개발 이 중요한 대안으로 제시되고 있다[8, 9]. 또한, 내성 세균의 증 가는 감염병치료에 많은 어려움을 야기하고 있으며 전통 약물 같은 천연자원에 존재하는 항균성 물질을 치료에 이용하고자 하는 연구가 활발히 수행되고 있다[10, 11]. 본 연구에서 이용된 Scutellaria scordifolia Fisch. ex Schrank식물은 대부분 관목 (Shurbs)와 허브(Hurbs)류로 이루어져 있는데 Lamiceae과 식 물은 주로 지중해 연안(Mediterranean region)에 널리 분포되 어 있으며, 특히 레바논(Lebanon)지역에는 29종(Genera)의 식물이 재배되고 있는것으로 알려져 있다[12]. 이 식물은 주로 관목용 및 식용 목적의 재배가 이루어 지고 있어 해당 지역에서 주요 경제적 이익을 창출하는 식물이다. Lamiceae과 식물은 외 선형 구조(external grandular structure)로 인해, 방향족 (aromatic) 성격을 띄고 있으며,이러한 특이 구조로 인해 volatile 오일을 생산해 내는 것으로 알려져 있다[13]. 레바논 지 역에서는 Lamiceae과의 식물에서 추출한 오일을 이용해 류마 티스 관절염 및 신경통의 전통 민간요법으로 사용되어 지고 있 다[13]. 이에 본 연구에서는 Lamicea과에 속해있는 Scutellaria scordifolia Fisch. ex Schrank 식물 추출물을 이용하여 폐렴 (pneumonia), 균혈증(bacteriemia) 및 항균제에 대한 내성 (antibiotics resistance)을 일으키는 Klebsiella pnemoniae균 을 대상[14]으로 병두황진(并头黄芩) 식물 추출물의 항균 효과 및 바이오필름 억제 효과에 대한 실험을 실시 하였다.

\section{재료 및 방법}

\section{1. 식물 추출액 및 사용 균주}

본 연구에 사용된 식물 추출액은 해외생물소재 센터(International Biological Material Research Center)에서 분양 받 아 사용하였다. 말린 Veronica longifolia, Aquilegia sibirica Lam, Oxytropis pseudoglandulosa Gontsch. ex Grub, Scutellaria scordifolia Fisch. ex Schrank $200 \mathrm{~g}$ 을 1.5 L 메탄 올 용액에 첨가 한 후, $50^{\circ} \mathrm{C}$ 에서 초음파로( 15 분/2시간 간격) 파 쇄하며 3일간 추출하였다. 식물추출액은 여과지로 필터 한 후, $45^{\circ} \mathrm{C}$ 에서 감압 농축하였으며, 농축 잔여물은 최종 동결 건조하 였다. 본 연구에서는 K. pneumoniae (ATCC 700831)를 Muller-Hinton (MH) agar, broth 배지(KisanBio, Korea)에 접종하여 $37^{\circ} \mathrm{C}$ 에서 24 시간 2 회 계대배양하여 활성화 한 후, 실 험에 사용하였다.

\section{Colony forming unit (CFU) 법}

식물추출액에 의한 균의 성장 억제 효과를 확인하기 위해 $\mathrm{CFU}$ 법을 이용한 생균수를 측정 하였다. 실험 전 K. pneumoniae 균을 $\mathrm{MH}$ agar에 도말 한 후, $37^{\circ} \mathrm{C} 18$ 시간 배양시켜 주 었다. 생성된 집락을 이용해 흡광도 $600 \mathrm{~nm}=0.1$ 의 균 부유액을 만들어 준 후, 다양한 농도의 식물 추출액와 함께 $37^{\circ} \mathrm{C} 24$ 시간 배양시켜 주었다. 이후, 배양액 $100 \mu \mathrm{L}$ 씩을 $\mathrm{MH}$ agar에 도말 하 여 $37^{\circ} \mathrm{C} 24$ 시간 추가 배양시켜 주었다.

\section{3. 세포독성 시험(LDH assay)}

$\mathrm{LDH}$ (lactate dehydrogenase) assay에 사용된 흰쥐의 섬유 아세포(L929)는Dulbeco's Modified Eagle's Media (DMEM) 배지(Gibco, USA)에 10\% FBS, 100 unit $\mathrm{mL}^{-1}$ 의 penicillin/ streptomycin을 첨가한 것을 사용 하였으며, $37^{\circ} \mathrm{C}, 5 \% \mathrm{CO}_{2}$ 배 양기를 이용하여 유지하였다.

$2 \times 10^{5}$ 의 L929세포를 96-well plate에 분주 한 후, 0.3, 0.6, $0.9 \mathrm{mg} / \mathrm{mL}$ 의 최종 농도로 식물추출액과 혼합하여 $37^{\circ} \mathrm{C}, 5 \%$ $\mathrm{CO}_{2}$ 배양기에서 24 시간 동안 배양 하였다. 24 시간 후 배양 배 지 $50 \mu \mathrm{L}$ 와 동량의 $\mathrm{LDH}$ 기질 용액(Promega, USA)을 30분간 실온에서 반응시킨 후, $1 \mathrm{M}$ acetic acid 를 $50 \mu \mathrm{L}$ 씩 첨가하여 반 응을 정지시킨 다음, 분광광도계(spectrophotometry) $490 \mathrm{~nm}$ 파장에서 측정한 흡광도(optical density, OD) 값으로 세포독성 (cytotoxicity) 정도를 다음과 같이 백분율로 계산하였다. 이때 양성 대조군은 Triton X-100을 첨가하여 반응시킨 시료를 음 성 대조군은 배양액 만을 포함하는 시료를 사용하였다. 


\author{
세포독성 $(\%)=(\mathrm{X}-\mathrm{B}) /(\mathrm{A}-\mathrm{B}) \times 100$ \\ ( $\mathrm{X}$ : 실험군 $\mathrm{OD}$ 값, $\mathrm{A}$ : 양성대조군, $\mathrm{B}=$ 음성대조군 )
}

\section{4. 바이오필름 형성 억제 효과 평가시험 및 면역형광 염색법}

24-well plate (TPP, Trasad- ingen, Switzerland) 각 well 에 $10^{7} \mathrm{CFU} / \mathrm{mL}$ 조정한 균주액(MH broth)과 세포 독성이 없는 것으로 확인 된 $0.9 \mathrm{mg} / \mathrm{mL}$ 의 최종 농도로 식물추출액을 첨가 한 후, $37^{\circ} \mathrm{C}$ 에서 24 시간 동안 배양하였다. 음성대조군으로는 균주액만을 배양하였으며, 양성대조군으로는 gentamicin (final conc. $200 \mu \mathrm{g} / \mathrm{mL}$ )이 첨가된 균주액을 배양하였다.

배양이 끝난 실험군 및 대조군은 phosphate buffered saline (PBS)로 5회 세척한 후, 4\% paraformaldehyde로 실온 에서 20분간 고정시켜 주었다. 이후, Lipid A anti-LPS (Thermo, USA) 항체와 실온에서 1시간동안 반응시켜준 후, Donkey anti-goat alexa Fluor488 (Thermo, USA)을 실온 암 실에서 1 시간 추가 반응시켜 주었다. 모든 염색 과정이 끝난 후, confocal laser microscope (Olympus, Japan)을 이용해 바이 오필름 형성 여부를 관찰하였다.

\section{5. 통계처리}

본 실험에서 산출된 모든 결과 값들은 mean \pm standard deviation으로 나타내었다. 실험 군에 따른 데이터간의 통계적 유의성 검정을 위해 ANOVA와 student's t-test를 수행하였다 $(P<0.05)$.

\section{결 과}

\section{Scutellaria scordifolia Fisch. ex Schrank 식물 추출액에 의한 균 성장 억제 효과}

향균력이 있는 식물 추출액(Table 1)을 선별하기 위해 각각 의 식물 추출액 $0.5 \mathrm{mg} / \mathrm{mL}$ (최종 농도)과 O.D $600 \mathrm{~nm}=0.1$ 의 K. pneumoniae균 부유액을 함께 $37^{\circ} \mathrm{C}, 24$ 시간동안 배양 시켜 주었다. 이때, 음성대조군으로는 식물추출액과 동량인 $50 \mu \mathrm{L}$ 의

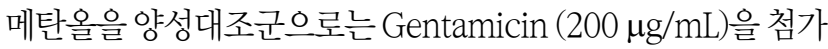
하여 동일한 조건으로 배양 하였다. 이 후, 생균수를 CFU법으로 측정하였다. 실험 결과, Scutellaria scordifolia Fisch. ex Schrank 을 첨가한 실험군 $\left(6.7 \log _{10} \pm 5.25 \mathrm{CFU} / \mathrm{mL}\right)$ 에서 다른 식물 추 출액 및 음성 대조군에 $\left(7.7 \log _{10} \pm 6.16 \mathrm{CFU} / \mathrm{mL}\right)$ 비해 통계적 으로 유의하게 K. pneumoniae 균의 성장이 억제 된 것을 확인 하였다(Figure 1).

\section{Scutellaria scordifolia Fisch. ex Shrank 식물 추출액의 흰쥐섬유아세포(L929)에 대한 세포독성 평가}

세포배양액만 첨가한 대조군은 $109.4 \pm 1.1 \%$ 의 세포 생존률 을 보였으며, $0.3 \mathrm{mg} / \mathrm{mL}$ 의 추출액 농도에 대해서는 $101.5 \pm 2.1 \%, 0.6 \mathrm{mg} / \mathrm{mL}$ 는 $98.0 \% \pm 2.8 \%, 0.9 \mathrm{mg} / \mathrm{mL}$ 는 $98.6 \pm 1.9 \%$ 의 세포생존율을 보임으로써 Scutellaria scordifolia Fisch.ex Schrank 추출물이 L929세포에 대한 세포독성을 띄 지 않음을 확인 하였다(Figure 2).

\section{Scutellaria scordifolia Fisch. ex Schrank 추출물의 농도별 K. pneumoniae 균 성장 억제 효과}

$\mathrm{LDH}$ 실험결과를 바탕으로 농도별 Scutellaria Scordifolia

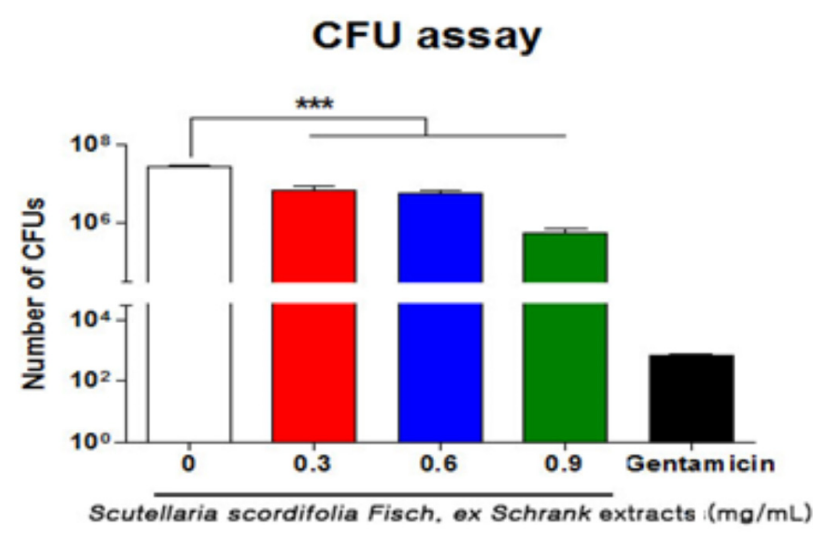

Figure 1. Measurement results of the bacterial number after incubation with the plant extraction solution (1: Veronica longifolia L., 2: Aquilegia sibirica Lam., 3: Oxytropis pseudoglandulosa Gontsch. ex Grub, 4: Scutellaria scordifolia Fisch. ex Schrank) (*** $P<0.001)$.

Table 1. Information on plant extracts used in this study

\begin{tabular}{ccccc}
\hline No. & Botanical Name & Family & Extracts & Traditional uses \\
\hline 1 & Veronica longifolia L. & Scrophulariaceae & Methanol & $\begin{array}{c}\text { Gastro-enteritis, Endometritis/aundic, } \\
\text { Cold-cough, Short breath, Lung tuberculosis }\end{array}$ \\
2 & Aquilegia sibirica Lam. & Ranunculaceae & Methanol & Gastro-intestinal function, Chronic gastritis, Colitis \\
3 & Oxytropis pseudoglandulosa Gontsch. ex Grub. & Fabaceae \\
4 & Scutellaria scordifolia Fisch. ex Schrank & Methanol & Stomatitis \\
& & & Methanol & Gastrointestinal diseases, \\
& & & Kidney and liver colics, Malaria, Anorexia, \\
\hline
\end{tabular}


Fisch. ex Schrank 추출물의 향균효과를 확인하였다. O.D $600_{\mathrm{nm}}=0.1$ 의 K. pneumoniae균 부유액을 $0.3,0.6,0.9$ $\mathrm{mg} / \mathrm{mL}$ 의 각기 다른 Scutellaria scordifolia Fisch. ex Schrank 추출물과 함께 $37^{\circ} \mathrm{C} 24$ 시간 배양하였으며, 이 후 생균수를 $\mathrm{CFU}$ 법으로 측정 하였다.

실험 결과, Scutellaria scordifolia Fisch. ex Schrank 추출 액이 첨가되지 않은 대조군에서는 $7.9 \log _{10} \pm 6.28 \mathrm{CFU} / \mathrm{mL}$ 의 생균수가 측정된 반면, 식물 추출액에 첨가된 실험군에서는 0.3 $\mathrm{mg} / \mathrm{mL}$ (7.9 $\left.\log _{10} \pm 6.28 \mathrm{CFU} / \mathrm{mL}\right), 0.6 \mathrm{mg} / \mathrm{mL}\left(7.17 \log _{10} \pm 6.5\right.$ $\mathrm{CFU} / \mathrm{mL}), 0.9 \mathrm{mg} / \mathrm{mL}\left(5.9 \log _{10} \pm 5.45 \mathrm{CFU} / \mathrm{mL}\right)$ 로 추출액의 농도 비례하게 생균수가 최대 약 60 배 억제 되었음을 확인 하였 다(Figure 1).

\section{Scutellaria scordifolia Fisch. ex Schrank 추출물의 K. pneumoniae균 바이오필름 형성 억제효과}

Scutellaria scordifolia Fisch. ex Schrank식물 추출액의 K. pneumoniae균 바이오 필름 형성 억제능을 확인하기 위해 Lipid-A항체를 이용한 면역 형광염색법(immunofluorescence staining)을 시행하였다. Lipid-A는 Acylated glucosamine phosphate disaccharide로써 LPS (lipopolysaccharide)의 구 성 성분이며, 그람 음성세균의 외막에 존재하고 있다. Lipid-A 항체를 이용하여 K.pneumoniae균을 염색 하였으며, confocal microscope을 이용하여 바이오필름 형성 유무를 시각화하였 으며, 형과세기(fluorescent intensity) 값을 바탕으로 정량화 하였다. 24-well plate에 $10^{7} \mathrm{CFU} / \mathrm{mL}$ 으로 조정한 K. pneumoniae 부유액과 앞선 CFU실험에서 균 성장 억제 효과를 최대 로 보인 $0.9 \mathrm{mg} / \mathrm{mL}$ 의 Scutellaria scordifolia Fisch. ex Schrank 식물 추출액을 혼합하여, $37^{\circ} \mathrm{C} 24$ 시간 동안 배양해주 었다. K. pneumoniae 균에 의한 바이오 필름 형성이 억제 유무
는 differential interference contrast (DIC) 및 형광 파장(488 $\mathrm{nm}$ )을 이용한 형광세기(fluorescence intensity)로 비교분석하 였다(Figure 3A, 3B). 실험 결과, 음성대조군에 비해 Scutellaria scordifolia Fisch. ex Schrank 추출물이 포함된 실험 군에서 $K$. pneumoniae 균의 개체수가 줄어 들어 있음을 DIC이미지를 통 해 확인하였으며, 형광세기의 비교.분석을 통해 음성대조군

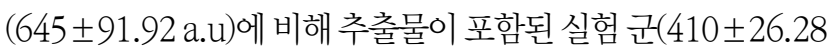
a.u)에서 형광세기가 통계학적으로 유의하게 낮아져 있는 것을 확인하였다(Figure 3B).

\section{고 찰}

Klebsiella는 그람음성 막대균으로 폐렴, 요로감염 그리고 연 골 조직 감염, 균혈증 등과 같은 감염을 일으키고 이 질환들을 막 기 위해 요즘 많은 방법들을 찾아내고 있다[15, 16]. 특히 $K$. pneumoniae는 병원 내에서 획득한 내성유전자가 Extendedspectrum $\beta$-lactamase를 생성하여 항생제 내성을 초래하는

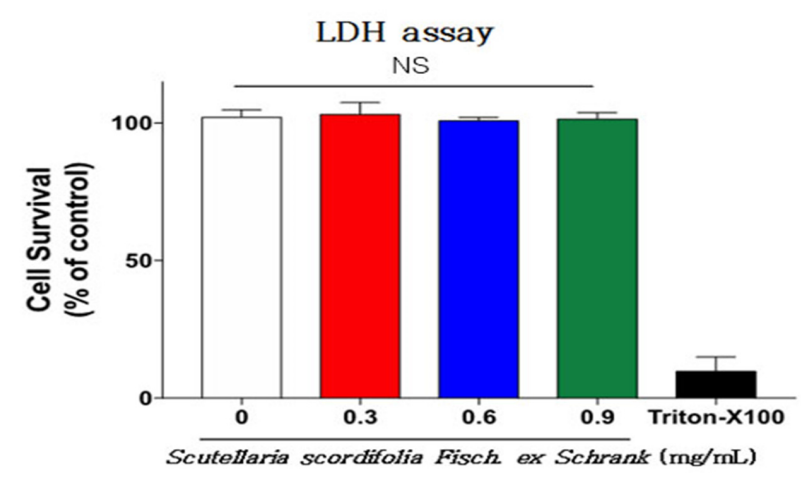

Figure 2. The results found after adding different concentrations of Scutellaria scordifolia Fisch. ex extracts to the L929 cells. Abbreviation: NS, no significance.
$3 A$.

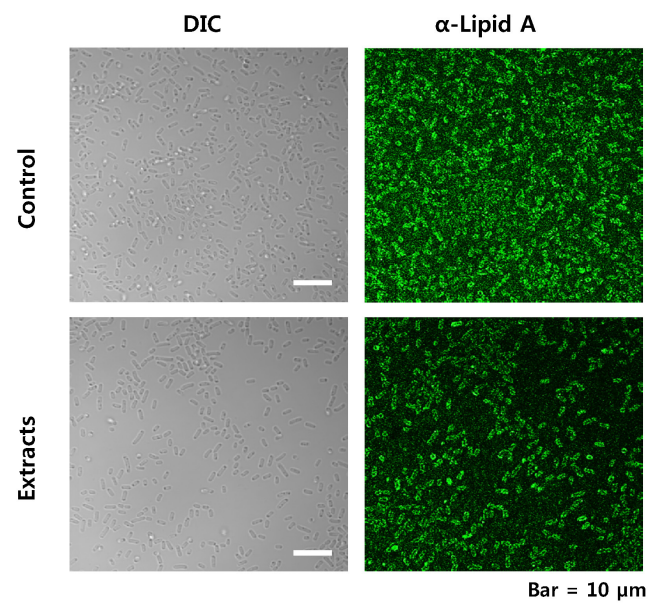

$3 B$.

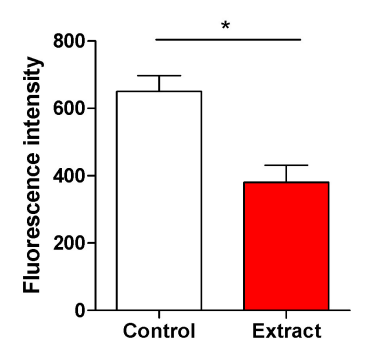

Figure 3. Biofilm inhibition effects of K. pneumoniae by Scutellaria scordifolia Fisch. ex Schrank extract $\left({ }^{\star} P\right.$ $<0.01)$. 3A: Comparing biofilm formation to $K$. pneumoniae with differential interface contrast (DIC) and fluorescent wavelength (488nm). 3B: Comparison of control and experimental groups for the number of $K$. pneumoniae by fluorscences intensity. 
것은 세계적인 문제가 되었고 적절한 감염관리와 항생제 관리 전략이 필요하다[17]. European Antimicrobial Resistance Surveillance System (EARSS)에 따르면, 유럽중에서 그리스는 K.pneumoniae에서 가장 높은 내성률을 보이고 있는데, 카바 페넴은 $46 \%$, 퀴놀론은 58\%, 3 세대 세팔로스포린은 $63 \%$ 이다 [18]. 한편, Hwang 등[19]은 우리나라에서 감염병 전문가 (infectious diseases specialist, IDS)가 주도하는 항생제 관리 프로그램(antimicrobial stewardship programmes, ASPs)은 대규모 병원 도 사망률에는 변화가 없으면서도 항생제 사용을 의미 있게 줄이고 항생제 내성률를 낮출 수 있게 하였다.

Scutellaria Scordifolia Fisch. ex Schrank은 Lamicea과에 속해 있는 식물로관상용및 식용으로 다양한지역(지중해연안)에서 재배 되고 있다. Lamicea과 식물은 페놀성분(phenolic compound)을 함유하고 있어 항산화(antioxidant) 및 항균(antibacterial)효과가 있는것으로 알려져 있으며20], Thyme (Thymus vulgaris L.), rosemary (Rosmarinus officinalis L.), oregano (Origanum

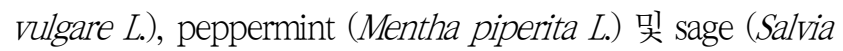
officinalis L.) 등 Lamicea과에 속하는 식물이 에탄올 기반추출물은 Proteus vulgaris, Listeria monocytogenes 1043S에 대한 항균력 이 있음을 확인 한 바 있으며 GC-MS실험결과, 이들 식물에는 Eugenol, Ledol성분이 다량 함유되어 있는것이 확인 되었다[21]. Eugenol 성분은 Salmonella typhi의 세포막의 거대분자를 변형시 킴으로 인해 투과성을 증대 시키는 원리로 향균효과가 있는것으로 보고 된 바 있으며[22], Ledol성분은 Escherichia coli, MRSA, K.pneumoniae에 대한향균력을 보이는 Nardostachys jatamansi 식물에 다량 포함되어 있는것으로도 보고된 바 있다[23].

본 연구에서는 Lamiceae과의 Scutellaria scordifolia Fisch. ex Schrank추출물의 기존에 알려져 있지 않은 향균력 및 바이 오필름 형성 억제력에 대한 실험을 진행하였다. Scutellaria scordifolia Fisch. ex Schrank 추출물의 흰쥐섬유아세포 (L929)에 대한 세포독성 평가를 실시하였다. L929는 일반적으 로 어떤 물질의 독성을 판단할 때 기준이 되는 세포로서 한국식 품의약품안전청에서 독성 평가 시에 사용 되는 세포주이다. 추 출물이 L929세포에 미치는 세포독성을 알아보기 위하여 MTT assay 를 시행하였다. $\mathrm{MBC}$ 농도를 기준으로 고농도와 저농도의 추출물을 사람 말초혈액세포 $\left(2 \times 10^{5} / \mathrm{well}\right)$ 와 24 시간 배양하 였다[19]. 실험결과, 세포배양액만 첨가한 대조군은 $109.4 \%$ 의 세포 생존률을 보였으며, $0.3 \mathrm{mg} / \mathrm{mL}$ 의 추출액 농도에 대해서 는 $101.5 \%, 0.6 \mathrm{mg} / \mathrm{mL}$ 는 $97.99 \%, 0.9 \mathrm{mg} / \mathrm{mL}$ 는 $98.63 \%$ 의 세포생존율을 보여 L929세포에 대한 세포독성을 띄지 않음을 확인 하였고 K.pneumoniae에 항균효과를 보였다. 추출액의
항균효과를 보기 위해 실시한 생균 수 측정과 바이오 필름 실험 (정량화 형광세기, fluorescence intensity)에서 균의 수가 유 의하게 낮아져 있는 것을 확인할 수 있었으며 통계적으로도 유 의한 차이를 보였다. 위 결과로 미루어 병두황진이 원내감염의 원인이 되는 폐렴 막대균 대한 항균성을 확인하였고 병두황진 을 활용한 더 많은 항균제 연구가 필요할 것으로 사료된다.

\section{요 약}

주술적 의료로 이용되는 식물에서 새로운 항미생물질을 찾는 있는 중에 바이오필름의 출현은 임상, 의학 제조업 분야에서 다 급한 신호를 보내주고 있는 것이다. 국립보건원(NIH)은 세계 모 든 미생물 감염의 $70 \%$ 가 바이오필름과 연관되어 있다고 추정하 고 있으며, 기존의 항생제에 내성이 있는 변종의 출현은 전세계 공중 보건에 심각한 위협이 되고 있다. 따라서 대체의학 물질을 찾아 내는 것은 통합(동서양) 의학의 중요한 화두이다. 이 연구에 서 Klebsiella pneumoniae의 바이오 필름 형성과 활성화에 대 한 네 가지 허브 추출물을 스크린 하였다. 본 실험에 사용된 식물 추출액 중에 Scutellaria scordifolia Fisch. ex Schrank 추출물 이 박테리아의 성장과 바이오 필름 형성에 억제 효과를 보여 주었 다. Scutellaria scordifolia Fisch. ex Schrank 추출물이 L929세 포에 대한 세포독성을 띄지 않음을 확인 하였다. Scutellaria을 첨 가한 실험군에서 다른 대조군에 비해 K. pneumoniae의 성장이 억제되었다. Scutellaria scordifolia Fisch. ex Schrank 추출액 이 첨가되지 않은 대조군과 비교하면, 식물 추출액이 첨가된 실 험군에서는 생균수가 최대 약 60배 억제되었음을 확인 하였다. Scutellaria scordifolia Fisch. ex Schrank 추출물이 포함된 실 험 군에서 K. pneumoniae 균의 개체수가 줄어들어 있음을 differential interference contrast (DIC)의 이미지를 통해서도 확인하였으며, 형광세기의 비교분석을 통해 음성대조군에 비해 추출물이 포함된 실험군에서 형광세기가 통계학적으로 유의하 게 낮아져 있는 것을 확인하였다. 이러한 결과는 이 식물 추출물 이 K. pneumoniae의, 특히 바이오필름 형성에서 항균제로서 적 용될 수 있음을 암시해 주는 것이다.

Acknowledgements: This study was supported by the Research Program (2016) funded by the Daejeon Health Institute of Technology.

Conflict of interest: None

Author's information (Position): Yook KD ${ }^{1}$, Professor; Ha $\mathrm{N}^{2}$, Researcher. 


\section{REFERENCES}

1. Grzegorczyk-Karolak I, Wiktorek-Smagur A, Hnatuszko-Konka $\mathrm{K}$. An untapped resource in the spotlight of medicinal biotechnology: The genus Scutellaria. Curr Pharm Biotechnol. 2018; 19:358-371.

2. Park HS, Park KI, Hong GE, Nagappan A, Lee HJ, Kim EH, et al. Korean Scutellaria baicalensis Georgi methanol extracts inhibits metastasis via the Forkhead Box M1 activity in hepatocellular carcinoma cells. J Ethnopharmacol. 2014;155:847851.

3. Velioglu YS, Mazza G, Cao L, Oomah BD. Antioxidant activity and total phenolics in selected fruits, vegetables, and grain products. J Agric Food Chem. 1998;46:4113-4117.

4. Gates MA, Tworoger SS, Hecht JL, De Vivo I, Rosner B, Hankinson SE. A prospective study of dietary flavonoid intake and incidence of epithelial ovarian cancer. Int J cancer. 2007; 21:2225-2232.

5. Shin SH, Sung IH. Antimicrobial activities of the extracts from Paeonia japonica against MRSA. Korean J Microbiol. 2006;42: 54-58.

6. Amin MU, Khurram M, Khattak B, Khan J. Antibiotic additive and synergistic action of rutin, morin and quercetin against methicillin resistant Staphylococcus aureus. BMC Complement Altern Med. 2015;15:59-72.

7. Hong SH, Lee CH. Antimicrobial activity of Houttuynia cordata ethanol extract against major clinical resistant microorganisms. Korean J Clin Lab Sci. 2015;47:140-146.

8. Mahady GB. Medicinal plants for the prevention and treatment of bacterial infections. Curr Pharm Des. 2005;11:2405-2427.

9. Chin JN, Jones RN, Sader HS, Savage PB, Rybak MJ. Potential synergy activity of the novel ceragenin, CSA-13, against clinical isolates of Pseudomonas aeruginosa, including multidrug- resistant $P$. aeruginosa. J Antimicrob Chemother. 2008;61:365370.

10. Liu IX, Durham DG, Richards RM. Baicalin synergy with $\beta$-lactam antibiotics against methicillin-resistant Staphylococcus sureus other $\beta$-lactam-resistant strains of $S$. aureus. J Pharm Pharmacol. 2000;52:361-366.

11. Jo SH, Cho CY, Ha KS, Choi EJ, Kang YR, Kwon YI. The antioxidant and antimicrobial activities of extracts of selected barley and wheat inhabited in Korean Peninsula. J Korean Soc Food Sci Nutr. 2013;42:1003-1007.
12. Khoury M, Stien D, Eparvier V, Ouaini N, Beyrouthy ME. Report on the medicinal use of eleven lamiaceae species in Lebanon and rationalization of their antimicrobial potential by examination of the chemical composition and antimicrobial activity of their essential oils. J Evid Based Complementary Altern Med. 2016;33:1-17.

13. Giuliani C, Bini LM. Insight into the structure and chemistry of glandular trichomes of Labiatae, with emphasis on subfamily Lamioideae. Plant Syst Evol. 2008;276:199-208.

14. Hong SN. Studies on antibiotics resistance of Klebsiella pneumoniae. Korean Journal of Medical Technologists. 1988; 20:175-181.

15. Wu HS, Wang FD, Tseng CP, Wu TH, Lin YT, Fung CP. Characteristics of healthcare associated and community acquired Klebsiella pneumonia bacteremia in Taiwan. J Infect. 2012;64:162-168.

16. Lata S, Sharma G, Sandhu HK. Antibacterial properties of various medicinal plants extracts against Klebsiella sp. Int Res J Environment Sci. 2014;3:75-78.

17. Paterson DL, Ko WC, Von Gottberg A, Mohapatra S, Casellas JM. Implications of extended-spectrum $\beta$-lactamase production in nosocomial infections. Ann Intern Med. 2004;140:26-32.

18. Souli M, Galani I, Giamarellou H. Emergence of extensively drug-resistant and pandrug-resistant Gram-negative bacilli in Europe. Euro Surveill. 2008;13:19045.

19. Hwang H, Kim B. Impact of an infectious diseases specialist-led antimicrobial stewardship programmes on antibiotic use and antimicrobial resistance in a large Korean hospital. Sci Rep. 2018;8:14757.

20. Alinezhad H, Baharfar R, Zare M, Azimi R, Nabavi SF, Nabavi SM. Biochemical activities of acetone extracts of Hyssopus angustifolius. Acta Pol Pharm. 2012;69:617-22.

21. Kozłowska M, Laudy AE, Przyby $\Varangle$ J, Ziarno M, Majewska E. Chemical composition and antibacterial activity of some medicinal plants from Lamiaceae family. Acta Pol Pharm. 2015;72:757-67.

22. Devi KP, Nisha SA, Sakthivel R, Pandian SK. Eugenol (an essential oil of clove) acts as an antibacterial agent against Salmonella typhi by disrupting the cellular membrane. J Ethnopharmacol. 2010;130:107-15.

23. Shrestha RL, Gautam SD, Shrestha S, Maharjan B. GC-MS analysis and antibacterial activity of Nardostachys jatamansi (D.Don) DC. Int J Pharm Sci Res. 2018;3:9-11. 